$$
\text { DOE/ER/14134 - } 8
$$

\title{
ELECTRON COLLISIONS WITH POSITIVE IONS
}

FINAL REPORT

\author{
Ronald J. Henry
}

Department of Physics

Auburn University

Auburn, AL 36849

June 15, 1990 - June 14, 1992

May 1997

Prepared for the U.S. Department of Energy under Contract No.

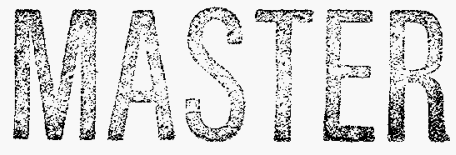
DE-FG05-90 ER 14134

\section{DISCLAIMER}

This report was prepared as an account of work sponsored by an agency of the United States Government. Neither the United States Government nor any agency thereof, nor any of their employees, makes any warranty, express or implied, or assumes any legal liability or responsibility for the accuracy, completeness, or usefulness of any information, apparatus, product, or process disclosed, or represents that its use would not infringe privately owned rights. Reference herein to any specific commercial product, process, or service by trade name, trademark, manufacturer, or otherwise does not necessarily constitute or imply its endorsement, recom. mendation, or favoring by the United States Government or any agency thereof. The views and opinions of authors expressed herein do not necessarily state or reflect those of the United States Government or any agency thereof. 


\section{DISCLAMMER}

Portions of this document may be illegible in electronic image produets. Images are produced from the best available origional document. 
This report concerns a program of computation of cross sections for electron impact excitation and ionization of ions. This is the final report which covers the period from June 15, 1990 to June 14, 1992 for grant No. DOE-FG05-90ER14134.

A review /1/ of progress made in the 1980s for calculations on electron impact excitation of atoms and ions for low and intermediate energy ranges concludes that the effect of continuum channels is very important to include in close coupling calculations. This may be achieved by use of pseudostates or the coupled-channels optical-potential method or the intermediate energy Rmatrix method. Those methods have been applied mainly to electron atom scattering to date and much remains to be accomplished in electron-ion scattering. Further, for multicharged ions, contributions of excitation-autoionization and resonant-excitation-double-autoionization to total ionization cross sections are important and underscore the role of two-electron correlation effects. Electron excitation data for alkali-like ions are reviewed in $/ 2 /$.

Detailed calculations are given for excitation-autoionization and resonant-excitation-doubleautoionization contributions to electron impact ionization cross sections for Li-like ions in /3/. Twelve autoionizing states arising from the $1 \mathrm{~s} 2 \mathrm{~s}^{2}, 1 \mathrm{~s} 2 \mathrm{~s} 2 \mathrm{p}, 1 \mathrm{~s} 2 \mathrm{p}^{2}, 1 \mathrm{~s} 2 \mathrm{~s} 3 \mathrm{~s}$, and $1 \mathrm{~s} 2 \mathrm{~s} 3 \mathrm{p}$ configurations, together with the ground $1 s^{2} 2 s$ and excited $1 s^{2} 2 p, 1 s^{2} 3 s, 1 s^{2} 3 p$, and $1 s^{2} 3 d$ states, are included in a close-coupling expansion. The cross sections are calculated at a large number of energy points and are then convoluted with a $2.0 \mathrm{eV}$ full-width-at-half-maximum Gaussian to simulate an experimental energy spread. Various measured featues by Hofmann et al. /4/ are reproduced well by the calculations.

Electron excitation cross sections are reported /5/ for the $3 \mathrm{~s}^{2} \mathrm{~S}->3 \mathrm{p}{ }^{2} \mathrm{P}$ resonance transition in $\mathrm{Mg}^{+}$at energies from threshold to approximately nine times threshold $(40 \mathrm{eV})$. Experiments are performed using electron-energy-loss and merged-beams methods. Calculations are made in two five state close coupling approximations. In addition, fifteen-state close coupling calculations made in $/ 6 /$ are used to determine the forward-to-backward correction required to extract experimental cross sections for $4 \mathrm{~s}^{2} \mathrm{~S}->4 \mathrm{p}^{2} \mathrm{P}$ in $\mathrm{Zn}^{+}$.

Relative level populations and density-sensitive emission-line ratios $R_{1}=I(18.687 \mathrm{~nm}) /(19.351$ $\mathrm{nm}), \mathrm{R}_{2}=\mathrm{I}(19.664 \mathrm{~nm}) / \mathrm{I}(19.351 \mathrm{~nm})$, and $\mathrm{R}_{\mathbf{3}}=\mathrm{I}(19.105 \mathrm{~nm}) / \mathrm{I}(19.351 \mathrm{~nm})$ were derived $/ 7 /$ using calculations /8,9/ of electron impact excitation rates for Fe XII. Excellent agreement was found with observations of solar active region and flare spectra obtained by the Naval Research Laboratory's S082A slitless spectrograph on board Skylab. The electron densities deduced from the Fe XII line ratios are also in agreement with those determined from Fe XIII and Fe XIV.

During the contract years $1990-92$, Dr.Henry spent $20 \%$ of his time working on this contract. Dr.Tayal spent $100 \%$ of his time. 


\section{References:}

1. R.J.W.Henry, Rep. Prog. Phys. 56, 327-362 (1993).

2. R.J.W.Henry, J. De Physique C1 57 (1991).

3. S.S.Tayal and R.J.W.Henry, Phys. Rev. A 44 , 2955 (1991).

4. G.Hofmann, A.Muller, K.Tinschert, and E.Salzborn, Z. Phys. D 16,113 (1990).

5. S.J.Smith, A.Chutjian, J.Mitroy, S.S.Tayal, R.J.W.Henry, F.-F. Man, R.J.Mawhorter, and I.D.Williams, Phys. Rev. 48, 292 (1993).

6. M.S.Pindzola, N.R.Badnell, R.J.W.Henry, D.C.Griffin, and W.L.vanWyngaarden ,Phys. Rev. A $\underline{44}, 5628$ (1991).

7. S.S.Tayal, R.J.W.Henry, F.P.Keenan, S.M.McCann, and K.Widing, Astrophys. J. $\underline{369}$, 567 (1991).

8. $\quad$ S.S.Tayal, R.J.W.Henry, and A.K.Pradhan, Astrophys. J. 319 , 951 (1987).

9. S.S.Tayal and R.J.W.Henry, Astrophys. J. $\underline{329}$, 1023 (1988). 
Articles published as a result of support from the grant.

Refereed publications:

DOE/ER/14134-01 Fe XII line ratios in solar flares.

S.S.Tayal, R.J.W.Henry, F.P.Keenan, S.M.McCann, and K.Widing

Astrophys. J. $\underline{369}$, 567-569 (1991).

DOE/ER/14134-02 Resonance-excitation-double-autoionization process in the electron-impact ionization of Li-like ions.

S.S.Tayal and R.J.W.Henry

Phys. Rev. A 44, 2955-2959 (1991).

DOE/ER/14134-04 Applying large computers to problems in physics: Electron Collision Cross Sections in Atomic Physics

R.J.W.Henry

Rep. Prog. Phys. 56, 327-362 (1993)

DOE/ER/14134-05 Electron Excitation Data for Alkali-like Ions

R.J.W.Henry

J. De Physique C1 57-59 (1991).

DOE/ER/14134-06 Close-Coupling Calculations for the Electron-Impact Excitation of $\mathrm{Zn}^{+}$

M.S.Pindzola, N.R.Badnell, R.J.W.Henry, D.C.Griffin, and

W.L.vanWyngaarden

Phys. Rev. A 44, 5628-5635 (1991).

DOE/ER/14134-07 Excitation cross sections for the $n s^{2} \mathrm{~S}->n p^{2} \mathrm{P}$ resonance transitions in $\mathrm{Mg}^{+}(\mathrm{n}=3)$ and $\mathrm{Zn}^{+}(\mathrm{n}=4)$ using electron-energy-loss and merged-beams methods

S.J.Smith, A.Chutjian, J.Mitroy, S.S.Tayal, R.J.W.Henry, F.-F. Man, R.J.Mawhorter, and I.D.Williams

Phys. Rev. A $\underline{48}, 292-309$ (1993).

Reports:

DOE/ER/14134-03 Electron Collisions with Positive Ions: Progress Report: 6/90 - 6/91

R.J.W.Henry

DOE/ER/14134-08 Electron Collisions with Positive Ions: Final Report: 6/90 - 6/92.

R.J.W.Henry 